\title{
Biological activity of mountain meadow subalpine soils of Central Caucasus
}

\author{
Fatima Gedgafova, Olga Gorobtsova, Tatyana Uligova, Rustam Tembotov*, and Elena Khakunova \\ Tembotov Institute of Ecology of Mountain Territories of Russian Academy of Science, 360051 Nalchik, Russia
}

\begin{abstract}
Indicators of biological activity (humic content and stock, Cmic content and stock, hydrolytic and redox enzymes activity) were measured for the first time in the upper horizons of mountain meadow subalpine soils of Central Caucasus (elbrus altitudinal zonality in Kabardino-Balkaria). The comparative assessment was performed for the biological characteristics together with soil density and acid-base properties for soils of natural and pasture ecosystems. The integral index of ecological and biological soil state (IIEBSS) was calculated to estimate the level of changes in biological activity. It was shown that pasture degradation leads to $30 \%$ decrease of IIEBSS compared to the undisturbed soil. The defined biological parameters of natural undisturbed mountain meadow soils could be used as diagnostic indicators for the ecological studies of ecosystems under anthropogenic load.
\end{abstract}

\section{Introduction}

The area of Kabardino-Balkaria, located on the northern slopes of the Central Caucasus, is only $12.500 \mathrm{~km}^{2}$, and half of its territory is occupied by mountain ranges. Due to the peculiarities of the physical-geographical and bioclimatic conditions, the high-mountain part of the Republic (1500-3500 above sea level) is characterized by a unique and diverse soil cover. In conditions of rugged terrain, up to 10 soil types with different genesis and properties were formed on slopes of various steepness and exposure [1-3].

Based on the analysis of available research and their own working material, the authors of [1-6] described in detail the specific conditions of mountain meadow soil formation, taking into account the local natural factors, and clarified the classification and systematics of highland soils. The features of the genesis and morphological characteristics of soils were described, a characteristic of the physicochemical properties and chemical and mineralogical composition was given, and the originality of the soils of the mountain regions of Kabardino-Balkaria was emphasized. However, despite the available notable research on high-mountain soils, the studies of their biological properties, in particular indicators of biological activity, are still lacking.

Of all the variety of soils in the mountain system of the Republic, the objects of this study were mountain meadow soils (subalpine subtype), that are common in the elbrus variant of the Kabardino-Balkaria zonality (typified by Tembotov A.K., 1989 [7]). These soils are more widespread than other types of mountain soils and occupy vast areas within the subalpine belt (1400-2800 above sea level). The considered mountain soils are characterized by a high content of coarsely dispersed humus $(15-20 \%)$ and its exceptional reserves in the upper horizons. This specific feature could be described by the climatic conditions of mountain landscapes, which provide constant sufficient soil moisture for the formation of rich meadow vegetation [3-6, 8-12].

Due to the unfavorable conditions of bedding along the relief, the studied mountain meadow subalpine soils are actively used for natural forage lands - mown lands and pastures [3-5, 11]. However, long-term unsystematic grazing of livestock leads to the transformation of the vegetation cover and, as a consequence, to the degradation of soil micro- and macrostructure, compaction of the upper soil layer, humus loss and inhibition of biochemical activity. As a result of the degradation of the soil and vegetation cover, especially deterioration of the species composition of phytocenoses, the productivity of forage lands decreased in some cases up to ten or more times [3,11].

In the current conditions, the collection of information and assessment of the degree of change in the biological properties of mountain meadow soils of pasture ecosystems is of particular relevance. Comparison of the biological characteristics of pasture soils with similar parameters of natural plots seems to be especially promising. Such a comparative analysis will make it possible to quantitatively assess the consequences of pasture load on the soil cover of mountain meadows. As follows from the literature [1329], the most informative and objective biological characteristics of soils are humic content, respiratory indicators of the metabolic activity of soil microbial biomass, the activity of redox and hydrolytic enzymes. The presented complex of biological indicators reflects the most important aspects of the soil biological properties: genetic, microbiological and biochemical. The integral index of ecological and biological soil state (IIEBSS), which summarizes the controlled biological parameters, is recommended to use as a criterion for assessing the overall biological activity of soils $[19,20]$.

In this research we performed the comparative assessment of indicators and the total level of biological 
activity in the upper horizons $(0-10 \mathrm{~cm})$ of mountain meadow subalpine soils of natural and pasture ecosystems of Central Caucasus (elbrus altitudinal zonality in Kabardino-Balkaria).

\section{Objects and methods}

The object of this study is mountain meadow subalpine soils located in the upland areas of the southwestern part of Kabardino-Balkaria (Fig. 1). In WRB soil classification [30] these soils are considered as part of the reference group of Umbrisols (Umbrisols).

The studied mountain meadow subalpine soils occur in the upper reaches of the Baksan gorge (South Elbrus region) of Kabardino-Balkaria on slopes of various steepness and exposure of the Main and Side ridges [15]. The soil-forming rocks are shale eluvium and diluvium, granites, gneisses, limestones, sandstones, etc. [3]. The most characteristic features of the soil cover of upland territories are numerous outcrops of rock material, high cobble content, denuded and warp soils [3, 9].

The climate of the region is cool and is characterized by excessive precipitation, which varies in different parts of the uplands and creates a leaching water regime of the soils $[3,9]$. The average annual precipitation is $900-1100$ $\mathrm{mm}$, the average annual air temperature ranges from 3.3 ${ }^{\circ} \mathrm{C}$ to $5.9{ }^{\circ} \mathrm{C}$, the hydrothermal coefficient is $2-3[3,4]$. The indicators of thermal regime decrease and annual precipitation increase with the height of the terrain, what is common for the alpine zone [5].

Mountain meadow soils are developed under forbcereal meadows dominated by Bromopsis variegate (M. Bieb.) Holub, Festuca varia Haenke, Festuca ovina L., Carex humilis Leyss., Alchemilla caucasica Buser, Anthoxanthum alpinum A. Love \& D. Love, Betonica macrantha C. Koch., that form dense root mat [3, 10, 11]. Projective coverage of species is $95-100 \%$. Plants that form subalpine meadow phytocenosis are up to 40 $50 \mathrm{~cm}$ high and are characterized by wide and deep root system. The stock of aboveground phytomass of the plant community in the air-dry mass is $20-50 \mathrm{c} / \mathrm{ha}$.

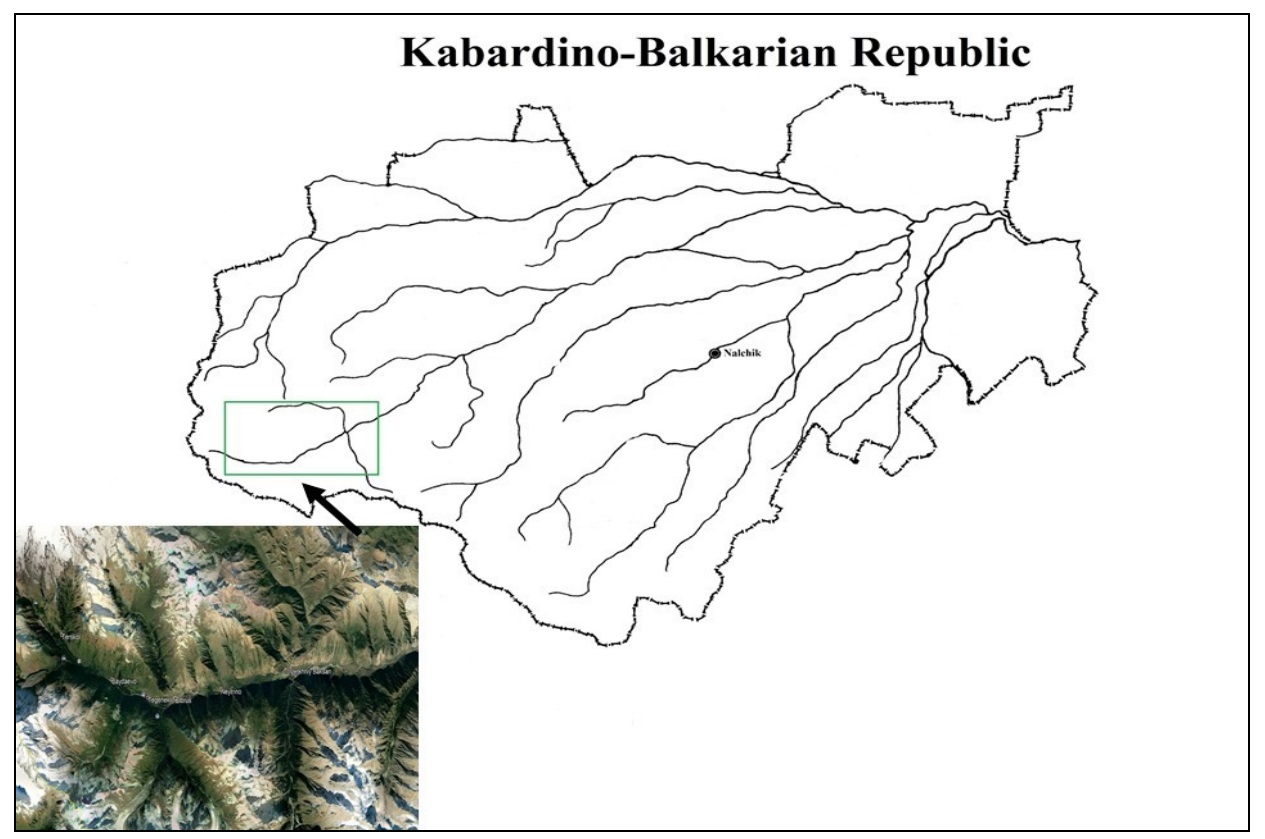

Fig. 1. Study area of mountain meadow subalpine soils of the elbrus variant of zonality within Kabardino-Balkaria

As a result of the long-term use of more than $30 \%$ of the area of upland meadows for hayfields and pastures, the species composition of the natural grass stand changed towards deterioration, there was a contamination of poisonous and harmful plants, such as Veratrum lobelianum Bernh., Potentilla bifurca L., Alchemilla caucasica Buser, Alchemilla retinervis Buser, Cirsium obvallatum (M. Bieb.) M. Bieb., Carduus nutans L. Under the conditions of pasture degradation, the total vegetation cover of herbage changes to $60-80 \%$, the height of the herbage decreases from $2-5 \mathrm{~cm}$ (trampled meadows) to $10-30 \mathrm{~cm}$ (ruderal communities). The stock of aboveground phytomass in the air-dry mass is $10-12 \mathrm{c} / \mathrm{ha}$. The nomenclature of species is given in accordance with The Plant List (http://www.theplantlist.org).

The collection and analysis of soil samples to determine the physicochemical and biological properties was carried out according to the methods generally accepted in ecology and soil science [20, 23, 31]. Soils were sampled by the envelope method in the upper horizon $(0-10 \mathrm{~cm})$ in natural and anthropogenically disturbed biogeocenoses (pasturess) in the first decade of July 2019-2020. The number of mixed soil samples was 7. Cartographic materials were used to choose the location of sampling points [32]. Altitude and geographic coordinates were determined using a GPSMAP 60 CEX navigator: altitude limits of sampling 
points - 1410-2355 $\mathrm{m}$ above sea level, coordinates 43.25578 - 43.34838 N., 42.48546 - 42.85082 E. (Fig. 1). The classification diagnostics was carried out according to the genetic classification of soils $[8,12]$

Laboratory analytical studies were performed three to six fold. Humus content was estimated using Tyurin's method with modification by Nikitin. Soil $\mathrm{pH}$ of salt extract $(\mathrm{KCl} 0,1 \mathrm{n})$ was estimated potentiometrically. Field soil moisture and soil density were estimated by gravimetric method [31]. Humus stock in 0-10 cm layer was calculated using soil density indices.

The rates of basal and substrate-induced respiration (BR and SIR) that characterize background and potential respiration activity were determined in accordance with the methodological developments of Ananyeva [23]. To calculate The carbon content of microbial biomass (Cmic) was calculated using the formula: Cmic ( $\mu \mathrm{g} \mathrm{C} / \mathrm{g}$ soil $)=\operatorname{SIR}(\mu 1 \mathrm{CO} 2 / \mathrm{g}$ soil $/$ hour $) \times 40.04+0.37$ [28] Cmic stock in 0-20 cm layer was calculated using soil density. The ratio of microbial biomass carbon in the total soil organic carbon was calculated as Cmic/Corg.

Specific respiration of microbial biomass (microbial metabolic quotient, $q \mathrm{CO} 2$ ) was calculated by ratio between basal respiration and microbial biomass: $\mathrm{BR} / \mathrm{Cmic}=q \mathrm{CO} 2(\mu \mathrm{g} \mathrm{CO} 2-\mathrm{C} \mathrm{m} / \mathrm{g} \mathrm{Cmic} /$ hour$)[22$, 23]. The value of the coefficient of microbial respiration was determined as the ratio of the BR rate to the SIR rate: $\mathrm{QR}=\mathrm{BR} / \mathrm{SIR}$. The $\mathrm{QR}$ ' value represents the ratio of the $\mathrm{QR}$ value in disturbed soils to the $\mathrm{QR}$ value in natural soils (QR' $=\mathrm{QR}$ disturbed / QR natural) [22].

Activities of urease, phosphatase, invertase, dehydrogenase were estimated colorimetrically; catalase activity was estimated gasometrically according to Galstyan's methods as modified by Khaziev [20]. Sterilized soils $\left(180{ }^{\circ} \mathrm{C}, 3\right.$ hours) served as a control for determining the enzyme activity. The obtained biological parameters were assessed using the scale of Gaponyuk E.I., Malakhova S.V. [33].

For a comparative assessment of the general level of biological activity of natural and pasture mountain meadow subalpine soils, we used the methodology for calculating the integral index of ecological and biological soil state (IIEBSS), which allows integrating the relative values of the studied parameters [19].

The obtained data was treated using STATISTICA 10 program. The significance of ifferences in the studied soil characteristics of the compared plots was assessed using the Student's t-test at a significance level of $\leq 0.05$.

\section{Results and Discussion}

When assessing the biological properties of mountain meadow subalpine soils under the influence of pasture loads, it is important to identify changes in acid- alkaline balance and soil bulk density. These indicators regulate enzymatic reactions and respiratory activity of soil microorganisms [13-15, 19].

The experimental data obtained showed that the soils of natural mountain meadow ecosystems are characterized by an acidic reaction of the soil solution (Table 1), which is due to the formation of organic acids during the decomposition of meadow vegetation [12]. In the process of pasture degradation, there is a weak tendency towards a decrease in the acidity level of the soil suspension within $8 \%(\mathrm{t}=2.03 ; \mathrm{P}=0.07)$. The $\mathrm{pH}$ level $(\mathrm{KCl} 0.1 \mathrm{n})$ of disturbed soils corresponds to the slightly acidic conditions of the soil solution.

Table 1. Average values of indicators of the upper horizons $(0-10 \mathrm{~cm})$ of mountain meadow subalpine soils

\begin{tabular}{|c|c|c|c|c|}
\hline \multirow{2}{*}{ Indicator } & \multirow[b]{2}{*}{$\begin{array}{c}\mathrm{pH}(\mathrm{KCl} \\
0.1 \mathrm{n} .) \\
\end{array}$} & \multirow{2}{*}{$\begin{array}{c}\text { Soil } \\
\text { density, } \\
\mathrm{g} / \mathrm{cm}^{3}\end{array}$} & \multicolumn{2}{|c|}{ Humus } \\
\hline & & & content, $\%$ & stock, t/ha \\
\hline Natural soils & $5.7 \pm 0.13$ & $0.66 \pm 0.01$ & $15.3 \pm 1.16$ & $202 \pm 11.66$ \\
\hline $\begin{array}{l}\text { Disturbed } \\
\text { soils }\end{array}$ & $6.2 \pm 0.18$ & $1.26 \pm 0.05$ & $8.1 \pm 0.93$ & $190 \pm 15.45$ \\
\hline
\end{tabular}

Note. $\pm \mathrm{m}$ is mean and error of the mean. The same in tables 2 , 3.

The indices of the bulk density characterize the upper horizons $(0-10 \mathrm{~cm})$ of mountain meadow soils of the background territories as loose, due to the large number of plant roots and organic matter in the silt fraction $[3,5$, $11,12]$. The main reason contributing to the upland soils compaction under pastures is physical activity in the form of intensive grazing. The average soil density of the studied soils under the conditions of pasture load on mountain meadows statistically significantly changes upward by $48 \%(\mathrm{t}=9.28 ; \mathrm{P}=0.00)$ in comparison with the natural soil. The observed process of compaction of mountain soils usually leads to a deterioration of the water-air properties, temperature and nutritional regimes of the vegetation cover, which can contribute to negative change in conditions for the development and functioning of microbial communities.

The humic content is one of the main characteristics of the biological activity of soils; it has a significant effect on the soil enzymes functioning and on the intensity of the respiratory activity of microbial communities [13-19]. According to previous research [1$6,11,13,21]$, natural soils of mountainous regions are distinguished by a high degree of humic content, due to the cold and humid climatic conditions and the peculiarities of the organic substances transformation caused by it. Rich meadow vegetation is formed due to the constant high soil moisture. The processes of plant residues decomposition are inhibited, and, basically, the accumulation of semi-decomposed organic matter takes place.

Studies show that the upper horizons $(0-10 \mathrm{~cm})$ of mountain meadow soils of natural ecosystems have a very high humic content, while in soils under pastures humic content is high. Obviously, due to the abundance of undisturbed vegetation, natural mountain soils are characterized by a high potential for humus formation and large reserves of humus. However, as a result of the annual grazing of pastures by animals, much less aboveground phytomass of the plant community, that is the main energetic substance of humus formation, enters the soil. The unsystematic use of subalpine meadows for grazing causes a significant loss of soil organic matter by 
$47 \%(\mathrm{t}=4.87 ; \mathrm{P}=0.00)$. Despite the noted decrease in the values of the analyzed parameter, the soils of pasture ecosystems retain a fairly high level of humic content (Table 1). In accordance with the rating scale [34], the humus stock in the upper horizons $(0-10 \mathrm{~cm})$ of the control natural soils should be assessed as very high, and in disturbed soils as high. The difference in mean values in the compared soils is only $6 \%(\mathrm{t}=0.11 ; \mathrm{P}=0.91)$. Less pronounced differences in this indicator are due to higher indices of bulk density in the soil samples from pasture plots.

The early indicators of changes in the natural environment under the influence of anthropogenic factors in the soil can be indicators of biological activity, such as basal respiration (BR), which reflects the availability of soil organic matter for soil microorganisms, and substrate-induced respiration (SIR), which characterizes the activity of the soil microbial community. The study of the response of soil microbial respiration in the conditions of pasture ecosystems is reflected in a number of works [22-27, 35-40].

Analysis of the obtained respiratory indicators of the metabolic activity of microbial biomass (Table 2) shown that the value of BR and SIR is influenced by the content of organic matter in subalpine soils. Obviously, the combination of a high humic content with favorable physical properties in the upper horizons $(0-10 \mathrm{~cm})$ of soils of mountain-meadow ecosystems (Table 1) creates optimal conditions for the functioning of soil microorganisms, which was confirmed in the studies of other authors [22-27].

Table 2. Average values of microbiological indicators of the upper horizons $(0-10 \mathrm{~cm})$ of mountain meadow subalpine soils

\begin{tabular}{|c|c|c|c|c|c|c|c|}
\hline \multirow[b]{2}{*}{ Indicator } & $\mathrm{BR}$ & SIR & \multicolumn{2}{|c|}{ Cmic } & \multirow[b]{2}{*}{ Cmic/Corg, \% } & \multirow[b]{2}{*}{$q \mathrm{CO}_{2}$} & \multirow[b]{2}{*}{$\mathrm{QR}$} \\
\hline & \multicolumn{2}{|c|}{$\mu \mathrm{CO}_{2} / \mathrm{g}$ soil / hour } & $\begin{array}{c}\text { Content } \\
\mu \mathrm{g} \mathrm{C} / \mathrm{g} \text { soil }\end{array}$ & $\begin{array}{l}\text { Stock } \\
\mathrm{g} / \mathrm{m}^{2}\end{array}$ & & & \\
\hline Natural soils & $16.1 \pm 1.7$ & $110.0 \pm 12.6$ & $2434 \pm 279.6$ & $347 \pm 29.9$ & $3.3 \pm 0.1$ & $1.65 \pm 0.2$ & 0.15 \\
\hline Disturbed soils & $10.6 \pm 0.8$ & $70.5 \pm 9.8$ & $1559 \pm 217.7$ & $349 \pm 27.7$ & $3.0 \pm 0.1$ & $1.96 \pm 0.2$ & 0.16 \\
\hline
\end{tabular}

Note:

1. Cmic content ( $\mu \mathrm{g} \mathrm{C} \mathrm{/} \mathrm{g} \mathrm{soil)} \mathrm{in} \mathrm{soil:} \mathrm{<} 200$ - very low, 201-500 - низкое; low, 501-1000 - mean, > 1000 - high [23]; 2. Level of soil microbial community disturbance: coefficient of microbial respiration $(\mathrm{QR})-0,1-0,2-$ no disturbance; $0,2-0,3-$ weak; $0,3-0,5-$ mean; 0,5-1,0 - strong; > 1,0 - catastrophic [22, 23].

For mountain meadow soils of pasture biogeocenoses, in comparison with natural soils, a weakening of the $\mathrm{BR}$ rate by $34 \%(\mathrm{t}=3.15 ; \mathrm{P}=0.01)$ was revealed, which indicates inhibition of the metabolic activity of soil microorganisms and the processes of mineralization of organic matter. The established significant suppression of the SIR rate by $36 \%(t=2.51$; $\mathrm{P}=0.03$ ) indicates the suppression of the physiological activity of the microbial community in the soils of pasture areas. According to the results of the correlation analysis in the studied subalpine soils, a close positive relationship was established between the real $(r=0.76)$ and potential $(\mathrm{r}=0.95)$ respiratory activity with the amount of organic matter.

The content of microbial biomass carbon (Cmic), determined using SIR method, is an important functional part of soil organic carbon, providing the main production of carbon dioxide by soils [22-28]. The soils of the natural mountain meadow ecosystems of the Republic, in accordance with the gradation [23], are distinguished by a very high level of Cmic content (Table 2), which characterizes them as soils with a high potential of microbial biomass. Under the conditions of pasture land use of subalpine meadows, the suppression of the microbial community is confirmed by a statistically significant decrease in this indicator by $36 \%$ $(\mathrm{t}=2.51 ; \mathrm{P}=0.03)$. However, despite the revealed decrease in the described parameter, the Cmic content in disturbed soils remains at a high level (more than 1000 $\mu \mathrm{g} \mathrm{C} / \mathrm{g}$ ), which indicates the presence of a sufficiently abundant microbial biomass, actively participating in microbiological processes in the changed ecological conditions of the natural environment.

The results of the correlation analysis showed a strong Cmic connection with a humic content $(\mathrm{r}=0.88$ 0.95 ) in soils of both natural and pasture ecosystems. The soils of the compared plots have similar average values of Cmic stock (Table 2), which is associated with higher values of the bulk density of the sample that characterizes the upper horizons of pasture soils.

The index of the ratio of microbial biomass carbon in the total organic carbon of the soil (Cmic / Corg) is considered as an ecophysiological parameter demonstrating the mobility and availability of soil organic carbon for microorganisms [22-26]. Comparative analysis of the Cmic / Corg ratios practically did not reveal any differences (only $9 \%, \mathrm{t}=$ 1.87; $\mathrm{P}=0.09$ ) between natural and disturbed soils (Table 2). Therefore, it can be assumed that the fixation of organic matter in the microbial biomass of the upper horizons $(0-10 \mathrm{~cm})$ of mountain meadow soils of pasture areas is comparable to that of soils of natural biogeocenoses.

Determination of the value of the microbial metabolic quotient $\left(q \mathrm{CO}_{2}\right)$, which simultaneously reflects changes in the values of the rate of $\mathrm{BR}$ and Cmic, allows one to assess the degree of resistance of microbial communities and soil as a whole to pastoral 
impact [22-26]. According to the previous research [22, 23], lower rate of specific respiration of microbial biomass is related to the higher stability of the ecosystem. The considered mountain soils of both natural and disturbed biogeocenoses have a small value of the described parameter (Table 2). With an adverse effect on the soil cover of the study area, there is only a tendency to an increase in the average $q \mathrm{CO} 2$ value (Table 2 ) by only $16 \%(\mathrm{t}=1.87 ; \mathrm{P}=0.09)$, which indicates a slight change in the ecophysiological state of microorganisms in pasture soils. The absence of significant differences in the $q \mathrm{CO} 2$ values of the compared soils may indicate the absence of a noticeable deterioration in the functioning of microbial processes under the pasture.

As an additional criterion for characterizing the degree of disturbance in the stability of the microbial community of high mountain soils, the relative coefficients of microbial respiration (QR-indicator of stress) were also calculated. The QR coefficients established in our study for the described soils of both natural and disturbed mountain meadow ecosystems are in the range of optimal values (from 0.1 to 0.2 ) [22-25]. The QR value exceeding the range of values - 0.2-0.3, indicates unfavorable climatic and anthropogenic influences [22]. Comparison of the calculated value QR $'=1.07$ with the data of the synecological scale of stability $[22,23]$, made it possible to note a weak degree of soil microbial community disturbance as a result of pasture use of mountain meadows. Obviously, the ability of soil microorganisms to withstand pasture pressure is largely due to the high content of Cmic (more than 1000 $\mu \mathrm{g} \mathrm{C} \mathrm{/} \mathrm{g)} \mathrm{in} \mathrm{mountain} \mathrm{meadow} \mathrm{soils} \mathrm{of} \mathrm{subalpine}$ pastures.

One of the objective indexes of general soil microbial activity is enzyme activity representing intensity and trends of biochemical processes. Researchers [13-15, 18, $19,41,42]$ propose to use enzyme activity as a potential indicator of soil quality due to its relationship with soil biota, simplicity of identification and rapid response to changes caused by anthropogenic impact.

In this research we defined the activity of two classes of soil enzymes: hydrolases (invertase, phosphatase, urease) and oxidoreductases enzymes (dehydrogenase, catalase). In investigated soils of both natural and disturbed ecosystems (Table 3) the analyzed redox enzymes have low activity [33]. Between hydrolases, all three enzymes have high activity in natural soil, but high activity was observed only for phosphatase and urease under pastures. The only exception is invertase enzyme: activity was reduced from high to medium level. According the obtained data, activity of redox enzymes reduces, when hydrolytic processes are active in soils of subalpine meadow ecosystems.

Table 3. Average values of enzyme activity in upper horizons $(0-10 \mathrm{~cm})$ of mountain meadow subalpine soils

\begin{tabular}{|c|c|c|c|c|c|}
\hline \multirow{2}{*}{ Indicator } & \multicolumn{3}{|c|}{ Hydrolase activity } & \multicolumn{2}{c|}{ Oxidoreductase activity } \\
\cline { 2 - 6 } & $\begin{array}{c}\text { Invertase, } \\
\mathrm{mg} \text { of glucose/ } \\
1 \mathrm{~g} / \text { day }\end{array}$ & $\begin{array}{c}\text { Phosphatase, } \\
\mathrm{mg} \\
\mathrm{P}_{2} \mathrm{O}_{5} / 100 \mathrm{~g} / \mathrm{hour}\end{array}$ & $\begin{array}{c}\text { Urease, } \\
\mathrm{mg} \mathrm{NH_{3 } ,} \\
10 \mathrm{~g} / \mathrm{day}\end{array}$ & $\begin{array}{c}\text { Dehydrogenase, } \\
\mathrm{mg} \mathrm{TPP}, \\
10 \mathrm{~g} / \mathrm{day}\end{array}$ & $\begin{array}{c}\text { Catalase, } \\
\mathrm{mgO}_{2} / 1 \mathrm{~g} / \mathrm{min}^{2}\end{array}$ \\
\hline Natural soils & $61,1 \pm 3,64$ & $93,5 \pm 3,96$ & $45,1 \pm 7,81$ & $6,8 \pm 0,84$ & $3,0 \pm 0,27$ \\
\hline Disturbed soils & $43,7 \pm 5,82$ & $70,6 \pm 9,34$ & $31,9 \pm 5,72$ & $5,4 \pm 0,48$ & $2,2 \pm 0,10$ \\
\hline
\end{tabular}

The obtained experimental data (Table 3) find confirmation in the studies of the authors [13, 19, 21] who noted that mountain soils of the Caucasus, due to the significant content of organic matter, have a high activity of hydrolases, while the catalytic action of redox enzymes is suppressed. A number of works [13-15] have shown that the activity of hydrolytic enzymes is in close correlation with the content of humus - a source, substrate and immobilizer of soil enzymes. As a result of the correlation analysis, an average and strong conjugate relationship with the amount of organic matter of the activity of urease $(r=0.52)$, phosphatase $(r=0.70)$ and invertase $(r=0.80)$ was established in mountain meadow soils.

Comparative analysis of the data obtained from disturbed and natural soils revealed almost the same level of reduction in the activity of both oxidoreductases by $21-27 \%$ and hydrolases by $24-29 \%$. It should be noted that the use of subalpine meadows for pastures does not cause such a negative impact on the activity of the analyzed enzymes. Thus, the absolute values of the activity of four enzymes in the process of pasture degradation changed within the gradation [33] that is characteristic for natural soils, with the exception of invertase. According to the available information [18, 19], of the measured hydrolytic enzymes, invertase activity is most highly dependent on the humic content.

For a comparative assessment of the level of total activity of measured soil enzymes of natural biogeocenoses with similar data on pasture soils, the indices of the total relative activity of hydrolases, oxidoreductases and total enzymatic activity were calculated. Analysis of the data obtained (Fig. 2) showed that, as a result of pasture impact on mountain meadow soils, the relative values of the parameters under consideration remain at a fairly high level, on average, to $74 \%$ of those undisturbed soils. The weakening of the intensity of both hydrolytic and redox processes proceeds in almost the same degree.

When calculating the integral index of ecological and biological soil state (IIEBSS), which characterizes the level of the total biological activity of the studied soils, the following biological parameters were taken into account: the content of humus and carbon of the 
microbial biomass, the activity of the five studied enzymes (dehydrogenase, catalase, invertase, phosphatase, and urease).

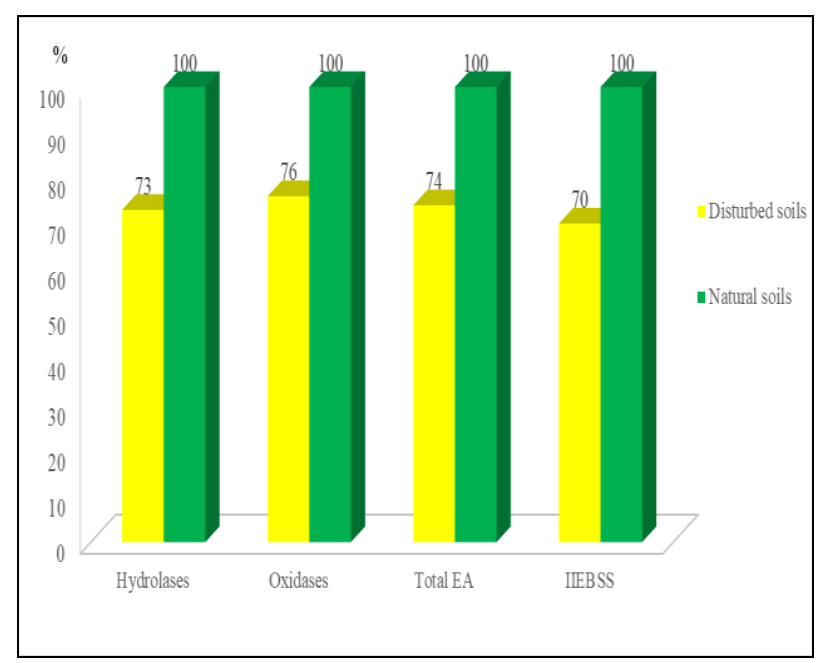

Fig. 2. The total relative activity of hydrolases, redox enzymes, enzymes of two classes and integral index of ecological and biological soil state (IIEBSS)values of the upper horizons (0-10 $\mathrm{cm}$ ) of mountain meadow subalpine soils

The diagram shown in Fig. 2, reflects the value of the IIEBSS of the upper horizons $(0-10 \mathrm{~cm})$ of mountain meadow soils of subalpine pastures, calculated relative to the indicator of the natural analogue (100\%). As follows from the comparative analysis, long-term extensive use of alpine meadows leads to a $30 \%$ decrease in IIEBSS compared to natural soil. According to the authors of [43], the loss of more than $30 \%$ of the bioenergetic potential is an excess of the stability threshold of soil systems and an indicator of a disturbance of their ability to restore their natural properties. It should be noted that the high natural productivity of mountain meadow subalpine soils and a decrease in IIEBSS value within the permissible norm of the ecological quality of soils allows them to maintain a stable state as a result of pasture use of meadow ecosystems.

\section{Conclusions}

Indicators of biological activity (genetic, microbiological, biochemical) in the upper horizons (0$10 \mathrm{~cm}$ ) of mountain-meadow subalpine soils of the Central Caucasus (elbrus variant of the zonation within Kabardino-Balkaria) have been comprehensively determined for the first time. The studied mountain soils of natural ecosystems are characterized by an acidic reaction of the soil solution $(\mathrm{pH} \mathrm{KCl} 0.1 \mathrm{n}=5.7)$, a very high humus content $(15.3 \%)$ and a low bulk density $\left(0.65 \mathrm{~g} / \mathrm{cm}^{3}\right)$.

It was found that in mountain meadow soils, as a result of intensive pasture load, there was a statistically significant decrease in the amount of organic matter (by $47 \%$ ) and an increase in the bulk density (by $48 \%$ ) with relatively stable values of humus and Cmic stocks.
The revealed decreases in the indicators of soil microbial respiration: the rate of $\mathrm{BR}-34 \%$ and SIR $36 \%$, the content of $\mathrm{Cmic}-36 \%$ indicate a possible deterioration in the functioning of the microbial community in disturbed soils. However, the recorded relatively small differences (only by $9-16 \%$ ) of the ecophysiological parameters: Cmic / Corg, $q \mathrm{CO} 2, \mathrm{QR}$ in the soils of pasture ecosystems from these reference indicators made it possible to note a low degree of disturbance in the stability of the microbial community as a result of pasture land use. The sharp decrease in the catalytic effect of hydrolytic enzymes by an average of $27 \%$ and redox enzymes - of $24 \%$ reflects almost the same level of changes in the intensity of biochemical processes that occur in the soil environment of pasture lands.

Soils of pasture ecosystems retain relatively high humic content $(8 \%)$ and stock (190 tonnes/ha), Cmic content (1559 $\mathrm{mkg} \mathrm{C} / \mathrm{g})$ and stock $\left(349 \mathrm{~g} / \mathrm{m}^{2}\right)$, high and medium levels of activity of hydrolytic enzymes. A decrease in the level of general biological activity within $30 \%$, the assessment criterion of which is the value of IIEBSS, indicates that mountain meadow soils of pasture ecosystems have not lost their bioenergetic potential and, under conditions of a decrease in pastoral load, are capable of self-restoration.

The defined most characteristic biological parameters of studied soils of natural mountain meadow ecosystems can be used as diagnostic indicators in environmental studies of anthropogenically disturbed biogeocenoses in the high-mountainous regions of the Central Caucasus.

\section{References}

1. A.N. Gennadiev, Pochvovedenie. E. 4, 122-131 (1978)

2. A.I. Romashkevich, A.V. Yashina, A.K. Borunov, Pochvovedenie. E. 5, 32-42 (1985)

3. B.Kh. Fiapshev, High-mountain soils of the central part of the North Caucasus (KBSACA Publ.; 1996.)

4. V.V. Razumov, Kh.A. Kurdanov, L.A. Razumova, A.G. Krokhmal, L.M. Batyrbekova, Ecosystems of Mountains of the Central Caucasus and Human Health (2003)

5. E.N. Molchanov, Pochvovedenie. E. 12, 1433-1448 (2010)

6. M.P. Volokitin, E. 5, 36-44 (2012)

7. V.E. Sokolov, A.K. Tembotov, Vertebrates of the Caucasus. Mammals. Insectivores, (Nauka, 1989)

8. Classification and diagnostics of soils of the USSR (Kolos, 1977)

9. Soils of Kabardino-Balkaria ASSR and recommendations on exploitation (Sevkavniigiprozem Publ.; 1984)

10. N.L. Tsepkova, R.Kh. Pshegusov, Z.M. Khanov, A.Zh. Zhashuev, E. 4-2, 428-432 (2015)

11. R.G. Gracheva, E.A. Belonovskaya, Geographic series. E. 1, 90-102 (2010) 
12. V.F. Valkov, S.I. Kolesnikov, K.Sh. Kazeev, Soils of the South of Russia (Publishing house "Everest", 2008)

13. A.S. Galstyan, Soils fermentation activity of Armenii (Aiastan, 1974)

14. F.Kh. Khaziev, System and ecological analysis of soil enzymatic activity (Nauka Publ, 1982)

15. S.A. Abramyan, Pochvovedenie. E. 7, 70-82 (1992)

16. A.M. Rusanov, Pochvovedenie. E. 11, 25-30 (1993)

17. Yu.G. Geltser, N.V. Mozharova, E.G. Kulagina, Pochvovedenie. E. 10, 1284-1290 (1995)

18. V.F. Valkov, K.Sh. Kazeev, S.I. Kolesnikov, Scientific ideas of the Caucasus E. 1, 32-37 (1999)

19. K.S.Kazeev, S.I. Kolesnikov, V.F. Val'kov, Soil biology of southern Russia (Izd-vo TsVVR, 2004)

20. K.Sh. Kazeev, S. I. Kolesnikov, Yu. D. Akimenko, E.V. Dadenko, Methods of bio-diagnostics of terrestrial ecosystems. (Southern Federal University. Rostov-on-Don, 2016)

21. E.V. Dadenko, K.S. Kazeev, S.I. Kolesnikov, E. 2, 345-348 (2016)

22. E.V. Blagodatskaya, N.D. Ananyeva, T.N. Myakishina, Pochvovedenie. E. 2, 205-210 (1995)

23. N.D. Ananyeva, Microbiological aspects of selfpurification and stability of soils (Nauka Publ.; 2003)

24. N.D. Ananyeva, E.A. Susyan, E.G. Gavrilenko, Pochvovedenie. E. 11, 1215-1221 (2011)

25. K.V. Ivaschenko, N.D. Ananyeva, V.I. Vasenev, V.N. Kudeyarov, R. Valentini, Pochvovedenie. E. 9, 1077-1088 (2014)

26. V.E. Prikhodko, M.L. Sizemskaya, Pochvovedenie. E. 8, 852-861 (2015)

27. S.V. Sushko, N.D. Ananyeva, K.V. Ivaschenko, V.N. Kudeyarov, Pochvovedenie. E. 9, 1091-1100 (2019)

28. J.P.E. Anderson, K.H. Domsch, Soil Biol. E. 10,
215-221 (1978)

29. E.B. Utobo, L. Tewari, Appl. Ecol. Environ. Res. E. 13/1, 147-169 (2015)

30. World Reference Base for Soil Resources. International soil classification system for naming soils and creating legends for soil maps. World Soil Resources Reports E. 106, 181 (2014)

31. V.V. Dobrovolsky, Workshop on soil geography (Vlados, 2001)

32. E.N. Molchanov, Explanatory Text to the Soil Map of Kabardino-Balkar Republic (GUGK SM SSSR, 1990)

33. E.I. Gaponyuk, S.V. Malakhov, (Gidrometeoizdat. 3-10, 1985)

34. V.F. Valkov, N.V. Eliseeva, I.I. Imgurt, K.Sh. Kazeev, S.I. Kolesnikov, Manual on soil assessmen (SUR Publishing House “Adygei” Publ., 2004)

35. R.T. Conant, K. Paustian, E.T. Ellot, Ecol. Appl. E. 11, 343-355 (2001)

36. E.L. Balota, A. Colozzi-Filho, D.S. Andrade, R.P. Dick, Biol. Fertil. Soils. E. 38, 5-20 (2003)

37. E.A. Stockdale, P.S. Brookes, J. Agricult. Sci. E. 144, 285-302 (2006)

38. Z.Solaiman, Soil Biol. E. 11, 201-211 (2007)

39. V. Acosta-Martínez, D. Acosta-Mercado, D. SotomayorRamírez, L. Cruz-Rodríguez, Appl. Soil Ecol. E. 38, 249-260 (2008)

40. R. Murugan, R. Loges, F. Taube, A. Sradnick, R.G. Joergensen, Microb Ecol. E. 67, 907-918 (2014)

41. A. Karaca, S.C. Cetin, O.C. Turgay, R. Kizilkaya, Soil Enzymol. Berlin: Springer Verlag. E. 22, 119 148 (2011)

42. M.A. Rao, R. Scelza, F. Acevedo, M.C. Diez, L. Gianfreda, Chemosphere. E. 107, 145-162 (2014)

43. A.S. Yakovlev, M.V. Evdokimova, Pochvovedenie. E. 5, 534-546 (2011) 